\title{
SISTEM PAKAR DIAGNOSA INFEKSI SALURAN PERNAFASAN PADA BALITA MENGGUNAKAN BAYESIAN NETWORK
}

\author{
Anton Setiawan Honggowibowo \\ Departemen Informatika \\ Sekolah Tinggi Teknologi Adisutjipto \\ JI. Janti Blok-R Lanud. Adisutjipto, Yogyakarta, 55198 \\ Email : anton_s_h@yahoo.com
}

\begin{abstract}
At present in developing countries, especially in Puskesmas very rarely encountered health workers, especially specialists. Though parents are in need of specialists, especially a specialist in the field of child health sciences. Puskesmas officials often have difficulty in deciding what diseases suffered by children because of lack of knowledge about the types of infectious diseases caused by bacteria. This is where the role of an expert or an expert in the field of childhood disease is needed. Therefore, to handle the problem it requires an expert system to diagnose respiratory infections in infants so that this system can be used to diagnose respiratory infections in infants using Bayesian Network method to determine what kind of illness and how to solve it.
\end{abstract}

Keywords : Expert System, Diagnosis of respiratory infection, Bayesian Network.

1. Pendahuluan

Istilah kesehatan dalam kehidupan sehari-hari sering digunakan untuk menyatakan bahwa sesuatu dapat bekerja secara normal. Kesehatan sangat penting nilainya dalam kehidupan manusia, akan tetapi sebagian orang mengangap remeh masalah kesehatan karena kurang pemahaman tentang pentingnya kesehatan, sehingga berakibat banyak orang yang meninggal dunia padahal hal itu dapat dihindari apabila ditangani dengan tepat. Salah satu penyakit yang dianggap remeh oleh masyarakat adalah penyakit infeksi saluran pernapasan akut (ISPA). Penyakit infeksi saluran pernapasan adalah salah satu penyakit yang harus diperhatikan dikalangan masyarakat luas karena bisa menyebabkan kematian, terutama pada balita. Dinas Kesehatan selalu melakukan upaya untuk mensosialisasikan dan mencegah penyakit infeksi saluran pernapasan pada balita karena masyarakat masih beranggapan bahwa penyakit infeksi saluran pernapasan adalah penyakit biasa-biasa saja, dikarenakan gejala awalnya adalah lemas, panas, letih dan mengeluarkan banyak keringat, sehingga terlambat dalam penanganan pihak medis.

Sistem pakar adalah sebuah sistem yang menggunakan pengetahuan manusia dimana pengetahuan tersebut dimasukan kedalam sebuah komputer dan kemudian digunakan untuk menyelesaikan masalah-masalah yang biasanya membutuhkan kepakaran atau keahlian manusia [1]. Sistem ini dapat diterapkan diberbagai bidang, salah satunya adalah bidang kedokteran dengan cara mendiagnosa suatu penyakit.

Selama itu, diagnosa penyakit bagi pasien masih harus melibatkan dokter secara langsung dengan cara dicatat dan dianalisa secara manual. Dengan kondisi seperti ini tentunya akan menimbulkan kendala bagi tenaga pelayanan kesehatan bahkan tidak menutup kemungkinan adanya kesalahan atau berbedanya diagnosa penyakit yang dialami oleh pasien. Salah satu alternatif untuk mengatasi kendala tersebut adalah dengan menganalisa menggunakan metode bayesian network pada sistem pakar diagnosa penyakit infeksi saluran pernapasan pada balita. Dengan alternatif ini diharapkan dapat meningkatkan kinerja pelayanan kesehatan. Diagnosa dengan 
menggunakan sistem pakar akan mencatat gejala-gejala dari pasien dan akan mendiagnosa jenis penyakit yang berbasis komputer sehingga dapat membantu pihakpihak terkait dalam melakukan diagnosa penyakit bagi pasien tersebut. Hal inilah yang menjadi acuan penulis untuk membahasnya dalam pembuatan penelitian yang berjudul "Sistem pakar diagnosa infeksi saluran pernafasan pada balita menggunakan bayesian network".

Adapun penelitian yang pernah dilakukan sebelumnya oleh peneliti lain yang relevan dengan penelitian ini adalah pada jurnalnya Wiweka [2] yang berjudul Sistem Pakar Diagnosa Infeksi Saluran Pernafasan Akut (ISPA) Menggunakan Logika Fuzzy menjelaskan bahwa sistem pakar diagnosa infeksi pernapasan akut (ISPA) adalah sebuah sistem yang mengadopsi kemampuan seorang pakar (dokter) dalam mendeteksi penyakit secara dini. Penyakit yang disebabkan ISPA tersebut antara lain adalah common coldl pilek, sinusitis, faringitis, laryngitis, bronchitis dan pneumonia. Semua penyakit tersebut rata-rata melalui parameter yang sama yaitu sebuah parameter yang didapat melalui anamnesia. Diantaranya melalui parameter demam, batuk, sesak napas, nyeri saat menelan dan lain-lain. Jadi untuk membangun sebuah sistem yang cukup dinamis dengan mengolah parameter yang ada tersebut menjadi sebuah pengetahuan yang menjadi dasar sebagai diagnosa perangkat lunak, maka dibutuhkan beberapa tahapan yang mulai dari akuisisi pengetahuan hingga representasi pengetahuan.

Sedangkan pada penelitian Latumakulita [3] dalam jurnalnya dengan judul Sistem Pakar Pendiagnosaan Penyakit Anak menggunakan Certianty Factor ( $\mathrm{CF}$ ) menjelaskan bahwa sistem pakar pendiagnosaan penyakit anak dengan menggunakan metode Certianty Factor (CF) dapat digunakan untuk mendiagnosa penyakit anak dengan tingkat kepercayaan yang telah ditentukan oleh pakar terhadap gejala-gejala yang mempengaruhi probabilitas terjadinya suatu penyakit anak. Sistem ini akan optimal jika seorang atau sekelompok pakar dalam hal ini dokter ahli anak telah mendefenisikan secara jelas nilai
CF setiap gejala penyakit terhadap kemungkinan terjadinya penyakit anak.

2. Metode Penelitian

Dalam penulisan ini akan dilakukan penelitian dengan melalui tahapan-tahapan sebagai berikut :

1. Metode Pengumpulan Data

a. Metode Pengamatan (Observasi)

Metode pengumpulan data yang dilakukan dengan cara mengamati secara langsung ke Puskesmas Gondomanan, kecamatan Gondomanan, Kota Yogyakarta.

b. Metode Wawancara (Interview)

Wawancara atau tanya jawab secara langsung dengan pihak-pihak terkait dalam hal ini seorang dokter guna mendapatkan data-data yang tepat sehingga aplikasi ini dapat sesuai dengan tujuan awal.

c. Metode Kepustakaan

Metode pengumpulan data kepustakaan ini untuk mendapatkan konsep teori mengenai masalah yang berhubungan dengan pengamatan, pembuatan program, serta mencari sumber data yang dibukukan atau jurnal yang telah ada sebelumnya.

2. Analisa Kebutuhan Sistem

Data yang dibutuhkan dalam pembuatan sistem pakar diagnosa infeksi saluran pernafasan pada balita adalah data-data gejala penyakit infeksi saluran pernafasan pada balita.

3. Perancangan sistem

Dalam diagnosa infeksi saluran pernafasan pada balita menggunakan perhitungan metode bayesian network.

4. Implementasi Sistem

Software dalam aplikasi sistem pakar diagnosa infeksi saluran pernafasan pada balita adalah bahasa pemrograman Delphi 7.

5. Pengujian Sistem

Sistem pakar diagnosa infeksi saluran pernafasan pada balita akan melakukan uji sistem dengan membandingkan hasil akhir dari metode bayesian network. Hasil pengujian akhir sistem didapatkan dari nilai perhitungan program dan nilai perhitungan manual. 


\subsection{Sistem Pakar}

Sistem pakar (Expert system) adalah sistem yang berusaha mengadopsi pengetahuan manusia ke komputer yang di rancang untuk menyelesaikan masalah seperti layaknya seorang pakar.

Keahlian di pindahkan dari seorang pakar ke suatu komputer. Pengetahuan ini kemudian disimpan didalam komputer, pada saat pengguna menggunakan komputer untuk mendapatkan informasi, sistem pakar menanyakan fakta-fakta dan dapat membuat penalaran (inferensi) dan sampai pada satu kesimpulan. Kemudian sistem pakar memberikan penjelasan (memberikan kesimpulan atas hasil konsultasi yang di lakukan sebelumnya) [4].

Pada dasarnya sistem pakar di terapkan untuk mendukung aktifitas pemecahan masalah. Beberapa pemecahan masalah yang dimaksud adalah pembuatan keputusan (Decision Making), pemaduan keputusan (knowlegde Fusing), pembuatan desain (Designing), perencanaan, (planning), prakiraan (forescating), pengaturan (Regulating), pengendalian (controlling), diagnosa (diagnosing), perumusan (prescribing), penjelasan (explaining), pemberi nasihat (advising) dan pelatihan (tutoring).

\section{2. Metode Bayesian Network}

Bayesian Network merupakan suatu probabilistic graphical model yang sederhana yang dibangun dari teori probabilistik dan teori graf. Teori probabilistik berhubungan langsung dengan data sedangkan teori graf berhubungan langsung dengan bentuk representasi yang ingin didapatkan. Bayesian network dapat mempresentasikan hubungan sebab akibat diantara variabel-variabel yang terdapat pada struktur bayesian network.

Bentuk teorema Bayes untuk evidence tunggal $\mathrm{E}$ dan hipotesis ganda $\mathrm{H1}, \mathrm{H} 2, \ldots \mathrm{Hn}$ [5] adalah :

$\mathrm{p}(\mathrm{Hi} \mid \mathrm{E})=\frac{p(E \mid H i) x p(H i)}{\sum_{k=1}^{n} p(E \mid H k) x p(H k)}$

Dengan:

$\begin{array}{ll}\mathrm{P}(\mathrm{Hi} \mid \mathrm{E})= & \begin{array}{l}\text { Probabilitas hipotesis } \mathrm{Hi} \\ \text { terjadi jika evidence } \mathrm{E} \\ \text { terjadi }\end{array} \\ \mathrm{p}(\mathrm{E} \mid \mathrm{Hi})= & \begin{array}{l}\text { Probabilitas munculnya } \\ \text { evidence } \mathrm{E}, \text { jika hipotesis Hi } \\ \text { terjadi }\end{array} \\ \mathrm{P}(\mathrm{Hi})= & \begin{array}{l}\text { Probabilitas hipotesis } \mathrm{Y} \\ \text { tanpa memandang evidence } \\ \text { apapun }\end{array} \\ \mathrm{N}= & \begin{array}{l}\text { Jumlah hipotesis yang } \\ \text { terjadi. }\end{array}\end{array}$

Untuk evidence ganda E1, E2,......Em dan hipotesis ganda $\mathrm{H} 1, \mathrm{H} 2, \ldots . \mathrm{Hn}$ adalah:

$\mathrm{P}(\mathrm{Hi} \mid \mathrm{E} 1 \mathrm{E} 2 \ldots \mathrm{Em})=$

$\frac{p(E 1 E 2 \ldots E m \mid H i) x p(H i)}{\sum_{k=1}^{n} p(E 1 E 2 \ldots E m \mid H k) x p(H k)}$

\section{3. Infeksi Saluran Pernafasan Akut (ISPA)}

ISPA merupakan singkatan dari infeksi saluran pernapasan akut. Istilah ISPA meliputi tiga unsur yakni infeksi, saluran pernafasan dan akut, dengan pengertian sebagai berikut:

a. Infeksi adalah masuknya kuman atau mikro organisme ke dalam tubuh manusia dan berkembangbiak sehingga menimbulkan gejala penyakit.

b. Saluran pernafasan adalah organ mulai dari hidung hingga alveoli beserta organ adneksa seperti sinus, rongga telinga tengah dan pleura. ISPA secara anatomis mencakup saluran pernafasan bagian atas, saluran pernafasan bagian bawah (termasuk jaringan paru-paru) dan organ adneksa saluran pernafasan.

c. Infeksi akut adalah infeksi yang berlangsung sampai dengan 14 hari. Batas 14 hari diambil untuk menunjukkan proses akut meskipun beberapa penyakit yang dapat digolongakan dalam ISPA proses ini dapat berlangsung lebih dari 14 hari.

Infeksi saluran pernafasan akut merupakan kelompok penyakit yang kompleks dan heterogen, yang disebabkan oleh berbagai etiologi. Etiologi ISPA terdiri dari 300 lebih jenis virus, bakteri dan riketsia serta jamur. Virus penyebab ISPA antara lain golongan mikrovirus (termasuk 
di dalamnya virus influenza, virus prainfluenza, dan virus campak). Bakteri penyebab ISPA misalnya streptokokus, hemolitikus, stafilokokus, hemofilis influenza, dan karinebakterium diffteris. Bakteri tersebut di udara bebas akan masuk dan menempel pada saluran pernafasan bagian atas yaitu tenggorokkan dan hidung. Bakteri tersebut biasanya menyerang anakanak yang memiliki kekebalan tubuh lemah. Anak-anak yang memiliki sistem kekebalan tubuh lemah pada umumnya bakteri pathogen dapat melewati mekanisme sistem pertahanan, sehingga dapat terjadi invasi didaerah-daerah saluran pernafasan atas maupun bawah.

Salah satu penularan ISPA adalah melalui udara yang tercemar dan masuk ke dalam tubuh memalui saluran pernafasan. Adanya bibit penyakit di udara umumnya berbentuk aerosol yakni suspensi yang melayang di udara, dapat seluruhnya berupa bibit penyakit atau hanya sebagian. Adapun aerosol dari penyebab tersebut ada 2 yakni droplet nuclei (sisa dari sekresi pernafasan yang ditularkan dari tubuh secara droplet dan melayang diudara) dan dust (campuran antara bibit penyakit yang melayang diudara). Adapun jenis-jenis penyakit ISPA adalah : [6]

a. Nasofaringitis

Nasofaringitis adalah infeksi primer pada nasofaring dan hidung yang sering mengeluarkan cairan, penyakit ini banyak dijumpai pada bayi dan anakanak.

b. Faringitis

Faringitis merupakan peradangan dinding faring yang dapat disebabkan oleh virus, bakteri, alergi, trauma, toksin.

c. Rinitis

Rinitis aadalah kelainan pada hidung dengan gejala bersin-bersin, rinore, rasa gatal dan tersumbat pada mukosa hidung.

d. Asma

Global Initiative for Asthma (GINA) mendefinisikan sebagai gangguan inflamasi kronik saluran nafas dengan banyak sel yang berperan, khususnya sel mast, eosinosil, dan limfosit $\mathrm{T}$.

e. Bronkitis
Bronkitis adalah suatu penyakit yang ditandai adanya dilatasi (ekstasis) bronkus lokal yang bersifat patologis dan berjalan kronik.

$f$ Pneumonia

Pneumonia adalah infeksi akut yang mengenai jaringan paru-paru (alveoli).

g. Tuberculosis (TBC)

Tuberculosis (TB) adalah infeksi bakteri pada paru-paru yang diperkirakan mempengaruhi sekitar sepertiga penduduk dunia.

\section{4. Representasi Pengetahuan}

Definisi representasi pengetahuan adalah proses pembentukkan suatu sistem pakar dengan mengambil data dari seorang ahli (human expert) atau dari nara sumber lainnya yang kemudian diolah menjadi suatu sistem pakar. Tujuan utama dalam representasi pengetahuan untuk menangkap sifat-sifat penting problema dan membuat informasi itu dapat diakses oleh prosedur pemecahan masalah. Representasi pengetahuan harus dirancang agar faktafakta dan pengetahuan lain yang terkandung di dalamnya dapat digunakan untuk penalaran.

Representasi pengetahuan yang digunakan adalah aturan berbentuk IFTHEN. Bentuk ini digunakan bila memiliki sejumlah pengetahuan pakar pada suatu permasalahan tertentu, dan pakar dapar dapat menyelesaikan masalah tersebut secara berurutan. Bentuk ini dapat digunakan saat dibutuhkan penjelasan mengenai langkah-langkah pencapaian solusi.

Aturan-aturan yang didapat dari pengetahuan pakar dan digunakan dalam membentuk representasi pengetahuan dalam penelitian ini antara lain:

[R1] IF rasa tidak enak pada hidung atau tenggorokan AND mengalami bersin-bersin AND hidung mengeluarkan cairan yang encer atau jernih (rinore) AND timbul demam ringan AND batuk ringan THEN Nasofaringitis.

[R2] IF rasa tidak enak pada hidung atau tenggorokan AND mengalami bersin-bersin AND hidung mengeluarkan cairan yang encer 
atau jernih (rinore). AND batuk ringan THEN Nasofaringitis

[R3] IF Tenggorokan sakit atau terasa nyeri AND Pembesaran kelenjar leher anterior AND Demam diatas $38^{\circ} \mathrm{C}$ AND Mengalami kesulitan saat menelan makanan atau minum AND Mengalami hilang nafsu makan AND Terdapat bintik merah terang dan nanah putih pada bagian belakang langit-langit dan amandel THEN Faringitis

[R4] IF hidung mengeluarkan cairan yang encer atau jernih (rinore) AND mengalami bersin lebih dari 5 kali bila terdapat kontak dengan debu, terutama pada pagi atau malam hari AND Hidung tersumbat AND Hidung dan mata terasa gatal, kadang disertai keluar banyak air mata (lakriminasi) AND Pucat THEN Rinitis Alergi

[R5] IF Hidung mengeluarkan cairan yang encer atau jernih (rinore). AND Mengalami bersin lebih dari 5 kali bila terdapat kontak dengan debu, terutama pada pagi atau malam hari. AND Hidung tersumbat AND Hidung dan mata terasa gatal, kadang disertai keluar banyak air mata (lakriminasi) AND Pucat AND Mengalami masalah penciuman AND Mengalami hilang nafsu makan THEN Rinitis Alergi

[R6] IF Hidung mengeluarkan cairan yang encer atau jernih (rinore) AND Mengalami bersin lebih dari 5 kali bila terdapat kontak dengan debu, terutama pada pagi atau malam hari. AND Hidung tersumbat AND Hidung dan mata terasa gatal, kadang disertai keluar banyak air mata (lakriminasi) AND Pucat AND Mengalami masalah penciuman AND Mengalami hilang nafsu makan AND Susah tidur THEN Rinitis Alergi

[R7] IF Mengalami mengi berulang-ulang AND Mengalami sesak nafas dan dada rasa tertekan, khususnya pada malam dan pagi hari AND Mengalami batuk khususnya pada malam dan pagi hari THEN Asma
[R8] IF Tenggorokan sakit atau terasa nyeri AND Sakit kepala AND Mengalami sesak nafas dan dada rasa tertekan, khususnya pada malam dan pagi hari AND Mengalami batuk khususnya pada malam dan pagi hari terjadi setiap hari selama 3bulan bahkan sampai 2 tahun. AND Produksi sputum atau dahak berwarna bening, putih atau hijau kekuningan AND Merasa mudah lelah THEN Bronkitis

[R9] IF Tenggorokan sakit atau terasa nyeri AND Demam diatas $38^{\circ} \mathrm{C}$ AND Sakit kepala AND Mengalami sesak nafas dan dada rasa tertekan, khususnya pada malam dan pagi hari AND Mengalami batuk khususnya pada malam dan pagi hari terjadi setiap hari selama 3bulan bahkan sampai 2 tahun. AND Produksi sputum atau dahak berwarna bening, putih atau hijau kekuningan THEN Pneumonia

[R10] IF Mengalami kesulitan saat menelan makanan atau minum AND Mengalami mengi berulang-ulang AND Mengalami nafas cepat dan sesak nafas AND Mengalami sulit bernafas disertai stridor (ngorok) AND Kejang THEN Pneumonia

[R11] IF Demam diatas $38^{\circ} \mathrm{C}$ AND Mengalami hilang nafsu makan AND Mengalami batuk kering AND Mengalami sulit bernafas AND Sering keluar keringat pada malam hari THEN Tuberculosis

3. Hasil dan Pembahasan

Implementasi sistem merupakan tahap penerapan sistem yang akan dilakukan jika sistem disetujui termasuk program yang telah dibuat pada tahap perancangan sistem agar siap untuk dioperasikan dan sesuai dengan apa yang diinginkan. Berdasarkan analisis dan desain sistem yang telah dilakukan maka telah diimplementasi sebuah sistem pakar untuk mendiagnosa penyakit saluran pernapasan pada balita menggunakan metode Bayesian Network. 
3.1 Implementasi Form Gejala

Form gejala ini digunakan untuk menyimpan data gejala yang berkaitan dengan sistem.

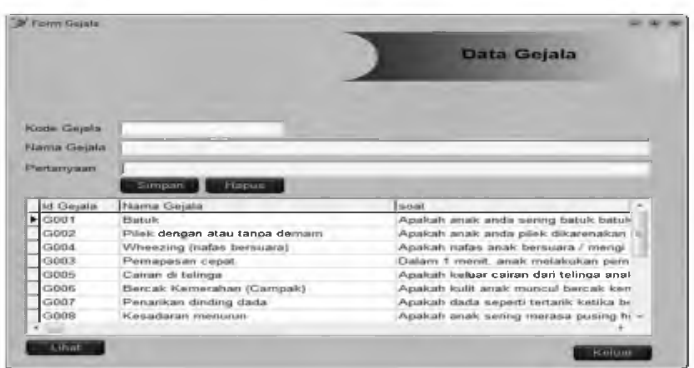

Gambar 1 Implementasi Form Gejala

\subsection{Implementasi Form Penyakit}

Form data penyakit digunakan untuk menyimpan data jenis- jenis penyakit yang akan ditangani.

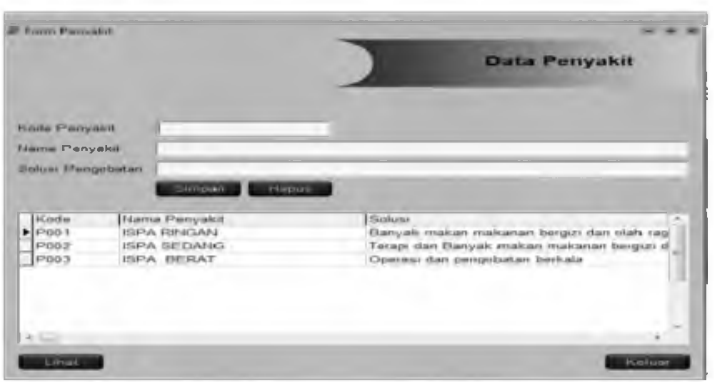

Gambar 2 Implementasi Form Penyakit 3.3 Implementasi Form Aturan Penyakit dan Gejala

Form aturan merupakan basis pengetahuan yang digunakan dalam menentukan probabilitas suatu gejala terhadap suatu penyakit.

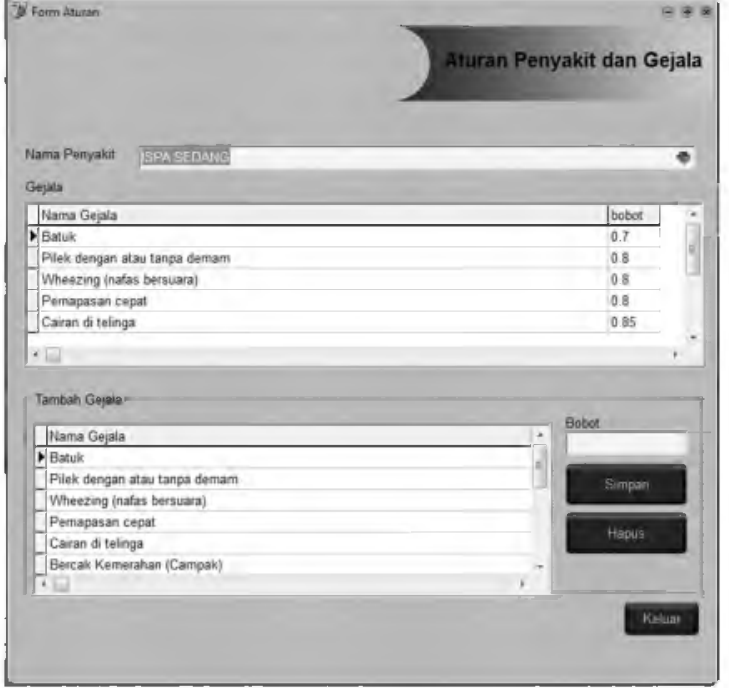

Gambar 3 Implementasi Form Aturan Penyakit dan Gejala

3.4 Implementasi Form Data Pasien

Form data pasien digunakan untuk menyimpan data-data pasien yang akan melakukan konsultasi.

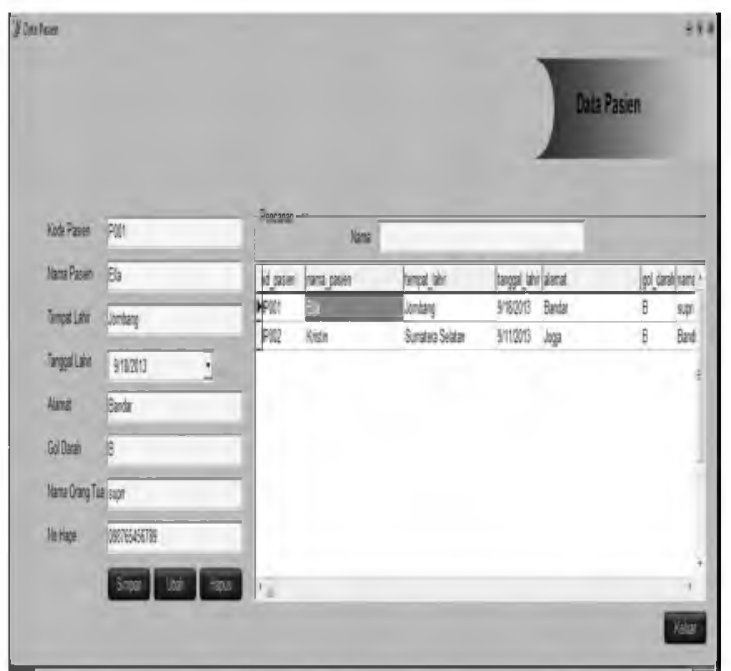

Gambar 4 Implementasi Form Data Pasien 3.5 Implementasi Form Konsultasi Pasien

Form konsultasi digunakan untuk melakukan konsultasi kepada pasien yang dilakukan oleh admin atau pakar dengan cara memberikan pertanyaan-pertanyaan yang berkaitan dengan gejala-gejala yang sesuai dengan data gejala. 


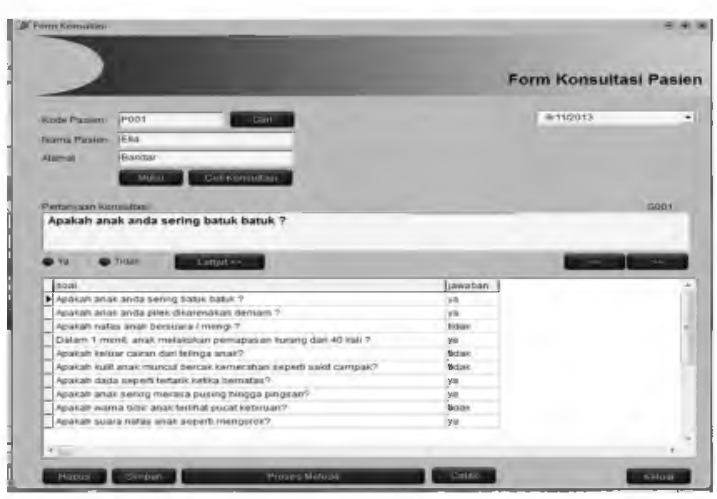

Gambar 5 Implementasi Form Konsultasi Pasien

\subsection{Implementasi Form Diagnosa} Menggunakan Metode Bayesian Network

Form diagnosa menggunakan metode bayesian berisi gejala-gejala yang dialami oleh pasien setelah melakukan konsultasi.

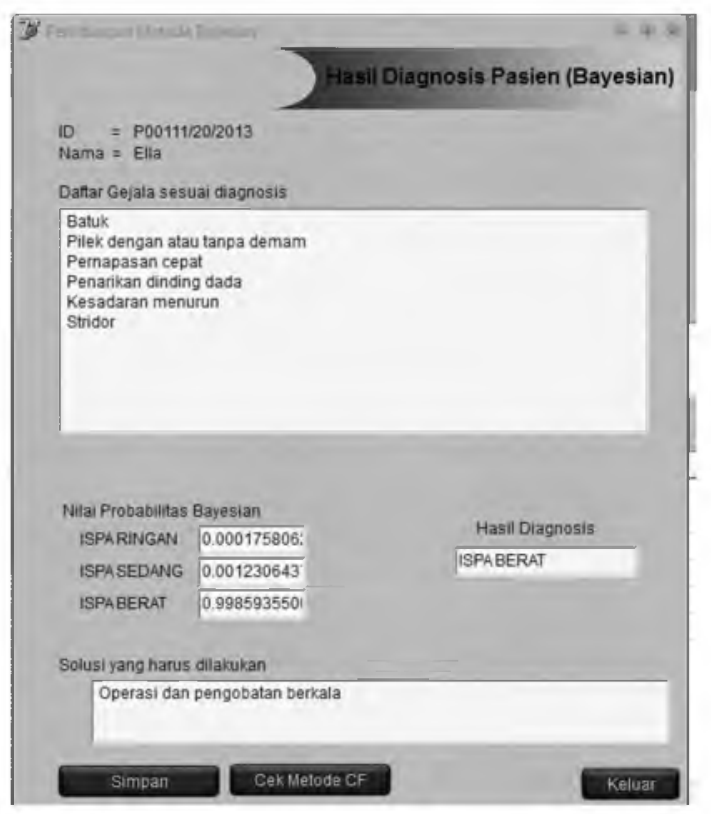

Gambar 6 Implementasi Form Perhitungan Bayesian Network

\subsection{Implementasi Hasil Akhir Diagnosa} Dokter

Form hasil akhir diagnosa dokter berisi hasil keputusan dari dokter tentang jenis penyakit apa yang diderita oleh pasien.

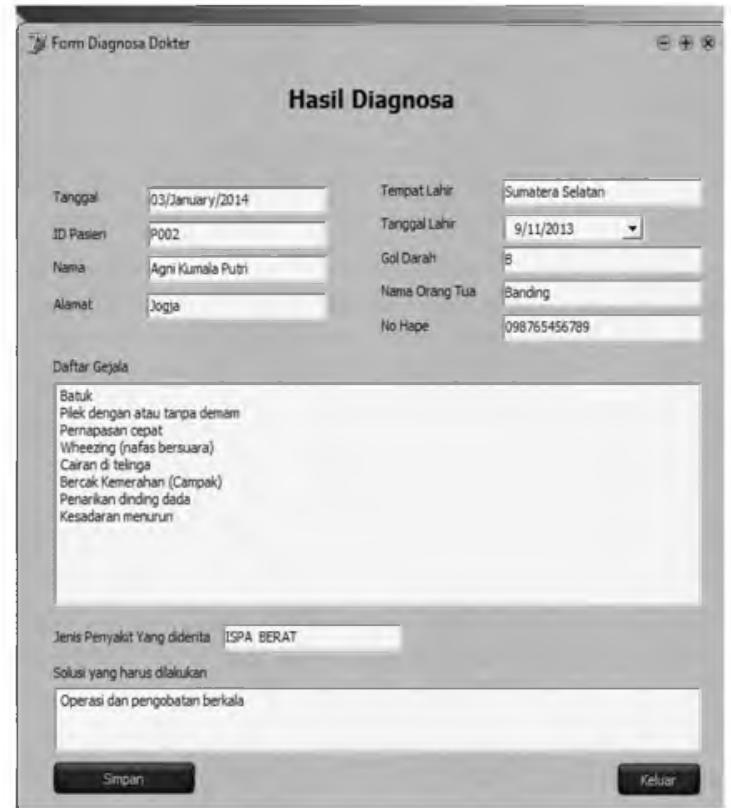

\section{Gambar 7 Implementasi Hasil Akhir Diagnosa Dokter}

Berdasarkan hasil perhitungan yang dilakukan maka didapat nilai Probabilitas ISPA Ringan $(\mathrm{H} 1)=0.000175806$, ISPA Sedang $(\mathrm{H} 2)=0.001230644$ dan ISPA Berat $(H 3)=0.99859355$. Berdasarkan ketiga nilai probabilitas diperoleh diambil nilai terbesar dari gejala-gejala tersebut yaitu H3 (ISPA BERAT) $=0.99859355$

Berdasarkan perhitungan yang dilakukan dengan menggunakan metode Bayesian Network terhadap gejala-gejala yang dialami oleh pasien menghasilkan keputusan yaitu pasien menggidap penyakit ISPA Berat.

\section{Kesimpulan}

Setelah melakukan analisa, perancangan dan pengujian sistem maka dapat diperoleh kesimpulan sebagai berikut :

1. Sistem pakar untuk mendiagnosa penyakit pernapasan menggunakan metode Bayesian Network menunjukan bahwa sistem pakar yang dibuat dapat melakukan diagnosa penyakit berdasarkan gejala-gejala yang dialami pasien.

2. Metode Bayesian Network sangat membantu dalam mencari hasil keputusan penyakit dari perhitungan sistem pakar untuk mendiagnosa 
penyakit pernapasan melalui uji fungsi yang dilakukan.

3. Sistem pakar untuk menentukan penyakit pernapasan menggunakan metode Bayesian Network dapat menyelesaikan masalah diagnosa penyakit infeksi saluran pernapasan karena dapat memberikan hasil dengan cepat dan nilai probabilitas kemunculan setiap jenis penyakit.

\section{Saran}

Saran yang dapat diberikan guna untuk perbaikan dan pengembangan dari aplikasi ini adalah :

1. Interaksi antara program aplikasi dengan pengguna sistem harus lebih ditingkatkan dengan tetap memperhitungkan aspekaspek interaksi manusia dan komputer, hal ini bertujuan untuk menghilangkan kejenuhan selama pengguna menggunakan program dalam waktu yang lama.

2. Sistem ini diharapkan dapat memberikan informasi yang akurat dengan melakukan percobaan - percobaan menggunakan banyak kombinasi data penyakit sehingga dapat menjadi perbandingan dalam penentuan jenis penyakit.

3. Gejala dan jenis penyakit masih sedikit, kiranya masih perlu ditambahkan sehingga untuk hasil yang diperoleh menjadi lebih baik.
6. Ucapan Terima kasih

Penulis mengucapkan terima kasih kepada Sekolah Tinggi Teknologi Adisutjipto yang telah memberi dukungan financial terhadap penelitian ini.

\section{DAFTAR PUSTAKA}

[1] Turban.E.dkk, 2005, Decision Support System And Intellegent System, Andi Offset, Yogyakarta.

[2] Wiweka.E.P, 2013, Sistem Pakar Diagnosa Infeksi Saluran Pernafasan Akut (ISPA) Menggunakan Logika Fuzzy, Jurnal Sistem dan Teknologi Informasi (JustIN) Vol 1 No 1 .

[3] Latumakulita, L.A., 2012, Sistem Pakar Pendiagnosaan Penyakit Anak Menggunakan Certianty Factor, Jurnal Ilmiah Sains (JIS) Vol 12 No 2.

[4] Sutojo.T, dkk. 2011, Kecerdasan Buatan, Andi Offset, Yogyakarta.

[5] Arhami, Muhammad., 2005, Konsep Dasar Sistem Pakar, Andi Offset, Yogyakarta.

[6] Direktorat Bina Farmasi Komunitas dan Klinik 2005, Pharmacuetical Care Untuk Penyakit Infeksi Saluran Pernafasan (ISPA), Direktorat Jendral Bina Kefarmasian dan Alat Kesehatan Departemen Kesehatan RI. 